\title{
Ultrastructural study of oogenesis in Marphysa sanguinea (Annelida: Polychaeta: Eunicida) from the Lagoon of Tunis
}

\author{
Monia Elbarhoumi ${ }^{1}$, Patrick Scaps ${ }^{2}$, Chakib Djediat ${ }^{3}$, Fathia Zghal ${ }^{1}$ \\ ${ }^{1}$ Laboratoire de Biologie de la Reproduction et du Développement animal, Faculté des Sciences de Tunis, \\ Campus universitaire, 2092 Tunis El Manar, Tunisie. \\ ${ }^{2}$ Laboratoire de Biologie Animale, Université des Sciences et Technologies de Lille, 59655 Villeneuve d'Ascq Cédex, \\ France. E-mail: patrick.scaps@univ-lille1.fr \\ ${ }^{3}$ Muséum National d'Histoire Naturelle, Paris, Service commun de Microscopie électronique des Laboratoires des Sciences \\ de la Vie. 57, rue Cuvier/case 39, 75231 Paris Cedex 05.
}

\begin{abstract}
Summary: Ultrastructural features of oogenesis of the iteroparous and long lived eunicid polychaete Marphysa sanguinea (Montagu, 1815) from the Lagoon of Tunis were studied using both light and transmission electron microscopy methods. The ovaries consist of coelomic germ-cell clusters surrounded by a thin envelope of follicle cells derived from the peritoneum. They are attached to the genital blood vessels. Oogenesis is asynchronous; therefore, germ cells in premeiotic and previtellogenic phases are observed in one cluster. The oogenesis is of the extraovarian type. In each cluster the more differentiated oocytes detach and float free in the coelomic cavity where they undergo vitellogenesis as solitary cells. Inside the ovary, follicle cells are connected to young oocytes by intercellular bridges and data suggest that in the early stages of vitellogenesis, ribosomes, multivesicular bodies and dense bodies are transferred from the follicle cells to the oocytes through the intercellular bridges. Different morphological evidence supports the heterosynthetic (presence of endocytotic vesicles, abundant microvilli adorning the surface of the egg) and autosynthetic (proteosynthetic organelles well developed, formation of blebs by the external membrane of the nuclear envelope) origin of yolk in $M$. sanguinea. The cytoplasmic material of the mature oocytes is asymmetrically distributed; large lipid droplets (1.5 $\mu \mathrm{m}$ in size) and large yolk spheres (6 $\mu \mathrm{m}$ in size) occupy the vegetal pole of the oocyte while small yolk spheres $(2-3 \mu \mathrm{m}$ in size) and numerous membranous organelles (mitochondria, cisternae of endoplasmic reticulum) occupy the animal hemisphere. Spherical to elongated cortical granules up to $1.8 \mu \mathrm{m}$ in size are located in the cortex of the mature oocytes. Finally, fibrogranular aggregates ("nuage") similar to that within the nucleus are observed in the cortical ooplasm located in the animal pole of mature oocytes. These aggregates probably come from the nucleus and represent maternal cytoplasmic determinants of embryonic cell fate. Oocytes that have completed vitellogenesis measure 250-300 $\mu \mathrm{m}$ in diameter.
\end{abstract}

Keywords: Marphysa sanguinea; annelid; Polychaete; oogenesis; vitellogenesis; ultrastructure.

Estudio ultraestructural de la ovogénesis en Marphysa sanguinea (Annelida: Polychaeta: Eunicida) en la Laguna de Túnez

Resumen: Se estudiaron las características ultraestructurales de la ovogénesis del poliqueto de la familia Eunicidae, Marphysa sanguínea (Montagu, 1815), caracterizado por ser iteróparo y presentar una largo periodo de vida vital. Los ejemplares proceden de la Laguna de Túnez y se estudiaron tanto mediante microscopía óptica como mediante microscopía electrónica de transmisión. Esta especie presenta ovarios consistentes en agrupaciones de células germinales celómicas rodeadas por una envoltura delgada de células foliculares derivado del peritoneo y unidos a los vasos sanguíneos genitales. La ovogénesis es asincrónica, por lo que se observan células germinales en fases premeióticas y previtelogénicas en cada clúster, y es de tipo extraovárico. En cada clúster, los ovocitos más diferenciados se desprenden y flotan libres en la cavidad abdominal donde experimentan la vitelogénesis como celdas aisladas. En el interior del ovario, los ovocitos jóvenes están conectados con células foliculares mediante puentes intercelulares, los cuales según los datos obtenidos, permiten la transferencia de ribosomas, cuerpos multivesiculares y cuerpos densos desde las células foliculares a los ovocitos en las primeras etapas de vitelogénesis. Diferentes pruebas morfológicas apoyan el origen heterosintético (presencia de vesículas endocitíticas, abundantes microvellosidades adornando la superficie del huevo) y autosintético (orgánulos proteosintéticos bien desarrollados, la formación de vesículas a partir de la membrana externa de la envoltura nuclear) del vitelo en $M$. sanguinea. El material citoplasmático de los ovocitos maduros se distribuye asimétricamente; grandes gotas de lípidos $(1,5 \mu \mathrm{m})$ y grandes esferas de vitelo $(6 \mu \mathrm{m})$ ocupan el polo vegetal del ovocito, mientras que esferas pequeñas de vitelo $(2-3 \mu \mathrm{m})$ y numerosos orgánulos membranosos (mitocondrias, cisternas del retículo endoplásmatico) ocupan el hemisferio animal. Los ovocitos maduros presentan gránulos corticales (entre esféricos y alargados y de hasta 1,8 um) en el córtex, mientras que en el ooplasma cortical del polo animal se presentan agregados fibrogranulares ("nuage") similares a los del núcleo. Estos agregados probablemente provienen del núcleo y representan determinantes citoplasmáticos maternos del destino de las células embrionarias. Una vez completada la vitelogénesis, los ovocitos miden entre 250-300 $\mu \mathrm{m}$ de diámetro.

Palabras clave: Marphysa sanguinea; anélidos; poliquetos; ovogénesis; vitelogénesis; ultraestructura. 
Citation/Como citar este artículo: Elbarhoumi M., Scaps P., Djediat C., Zghal F. 2014. Ultrastructural study of oogenesis in Marphysa sanguinea (Annelida: Polychaeta: Eunicida) from the Lagoon of Tunis. Sci. Mar. 78(1): 99-113. doi: http://dx.doi. org/10.3989/scimar.03863.27A

Editor: D. Martin.

Received: April 5, 2013. Accepted: October 8, 2013. Published: February 21, 2014.

Copyright: (C) 2014 CSIC. This is an open-access article distributed under the Creative Commons Attribution-Non Commercial Lisence (by-nc) Spain 3.0.

\section{INTRODUCTION}

Two basic patterns of oogenesis have evolved in the polychaetes: one (extraovarian) in which oocytes leave the ovary and undergo vitellogenesis while free floating in the coelomic fluid, with or without the aid of attached accessory cells or associated amoebocytes and another (intraovarian) in which oocytes undergo most of vitellogenesis while retained within the ovary in close association with follicle cells, nurse cells or blood vessels from which they may derive nutrients (Eckelbarger, 1983).

Comprehensive studies of oogenesis have been conducted in only $0.1 \%$ of described species (reviewed in Schroeder and Hermans, 1975, Eckelbarger 1983, 1984, 1988, 1992, 2005, 2006). Information about Eunicida oogenesis is very scarce. Eunicidae, as far as is known, are polytelic and gonochoric, without sexual dimorphism. Their reproductive habits, mainly studied for relatively few species of the genera Eunice, Lysidice, Marphysa, Nematonereis and Palola include free-spawning and brooding of the eggs, planktotrophic, lecithothophic, and direct development, as well as often schizogamy (epitoky) involving a modified posterior end full of gametes that is detached at maturity for spawning near the water surface (Wilson 1991, Giangrande 1997, Rouse and Pleijel 2001).

The polychaete Marphysa sanguinea (Montagu, 1815) (Eunicidae) was briefly described by Montagu in 1815 from the south coast of England. This species is recorded as a cosmopolitan species, distributed globally at temperate to tropical latitudes (e.g. Fauvel 1923, Hutchings and Karageorgopoulos 2003, Prevedelli et al. 2007). However, voucher specimens for many populations do not exist or were poorly identified. Taxonomists have recently reexamined many of these specimens, concluding that they may be a few to several different sibling species (Hutchings and Karageorgopoulos 2003, Prevedelli et al. 2007, Lewis and Karageorgopoulos 2008). All literature referring to $M$. sanguinea and its biology should therefore be referred to with caution. Furthermore, only fragmentary information is available concerning the reproductive biology of $M$. sanguinea (Prevedelli et al. 2007) and nothing is known about ultrastructural mechanism of oogenesis.

So, the aims of the present study were to analyze the oogenesis of $M$. sanguinea under light and transmission electron microscopy and to compare the obtained results with those in other polychaetes species, especially with other Eunicida. There are several reasons for choosing $M$. sanguinea as a model for the study of oogenesis in Eunicidae: adult worms are of rather large size and oocytes at all stages of oogenesis are present in females almost all year; therefore, substantial numbers of oocytes can be obtained for ultrastructural analysis.

\section{MATERIALS AND METHODS}

The Lagoon of Tunis, adjoining the city of Tunis, is located in the southwestern Gulf of Tunis (Fig 1A and B). It is a Mediterranean eutrophic coastal lagoon covering $45 \mathrm{~km}^{2}$ to an average depth of $1 \mathrm{~m}$. It is characterized by high fluctuations of physicochemical conditions. It is divided in two areas by a navigation channel (Fig. 1B). Individuals of Marphysa sanguinea (Montagu, 1815) were collected monthly in the navigation channel $\left(36^{\circ} 48.452^{\prime} \mathrm{N}\right.$; $\left.10^{\circ} 18.321^{\prime} \mathrm{E}\right)$ from May 2006 to May 2007. M. sanguinea is one of the most common species of errant polychaeta in the Lagoon of Tunis. Marphysa is a burrowing polychaete found in sandy and muddy environments or under stones. It attains a maximum length of about $40 \mathrm{~mm}$. The individuals occur low in the intertidal zone and extend down into the sublittoral; in consequence, individuals were collected in the intertidal zone. Reproductive characteristics were analyzed in all the individuals collected in an area of $2 \mathrm{~m}^{2}$ dug to a sediment depth of about 50 $\mathrm{cm}$. After collection, individuals were rinsed with filtered seawater and maintained individually in covered containers filled with about $100 \mathrm{ml}$ of filtered seawater. In the laboratory, a small quantity of very fine sand was added to containers. The containers were stored at $5^{\circ} \mathrm{C}$ before utilization.

As external sex differences are lacking in adults, the sex of each individual was determined after examination of coelomic punctures. In total, 320 females in various stage of sexual maturity were analyzed during this study.

Posterior segments were fixed for $3 \mathrm{~h}$ in a solution of $2 \%$ glutaraldehyde in $0.1 \mathrm{M}$ Sorrensen's phosphate buffer containing $0.18 \mathrm{M}$ sucrose at $\mathrm{pH}$ 7.4. Fixed tissue was rinsed three times for $20 \mathrm{~min}$ in Sorrensen"s phosphate buffer and post-fixed at room temperature in a solution of $1 \%$ osmium tetroxide in Sorrensen's phosphate buffer for $1 \mathrm{~h}$ adjusted to $\mathrm{pH}$ 7.4. After rapid dehydration through graded concentrations of ethanol $(30 \%, 70 \%, 90 \%$ and $100 \%)$, the fixed material was embedded in Spurr's resin. Ultrathin sections (60 nms) of embedded tissue were cut on a Porter Blum ultramicrotome (Reichert-Juing) with a diamond knife, contrasted by immersion in three baths of saturated uranyl acetate solution in 50\% methanol for $10 \mathrm{~min}$ and examined with a Hitachi H-7100 electron microscope. Imag- 

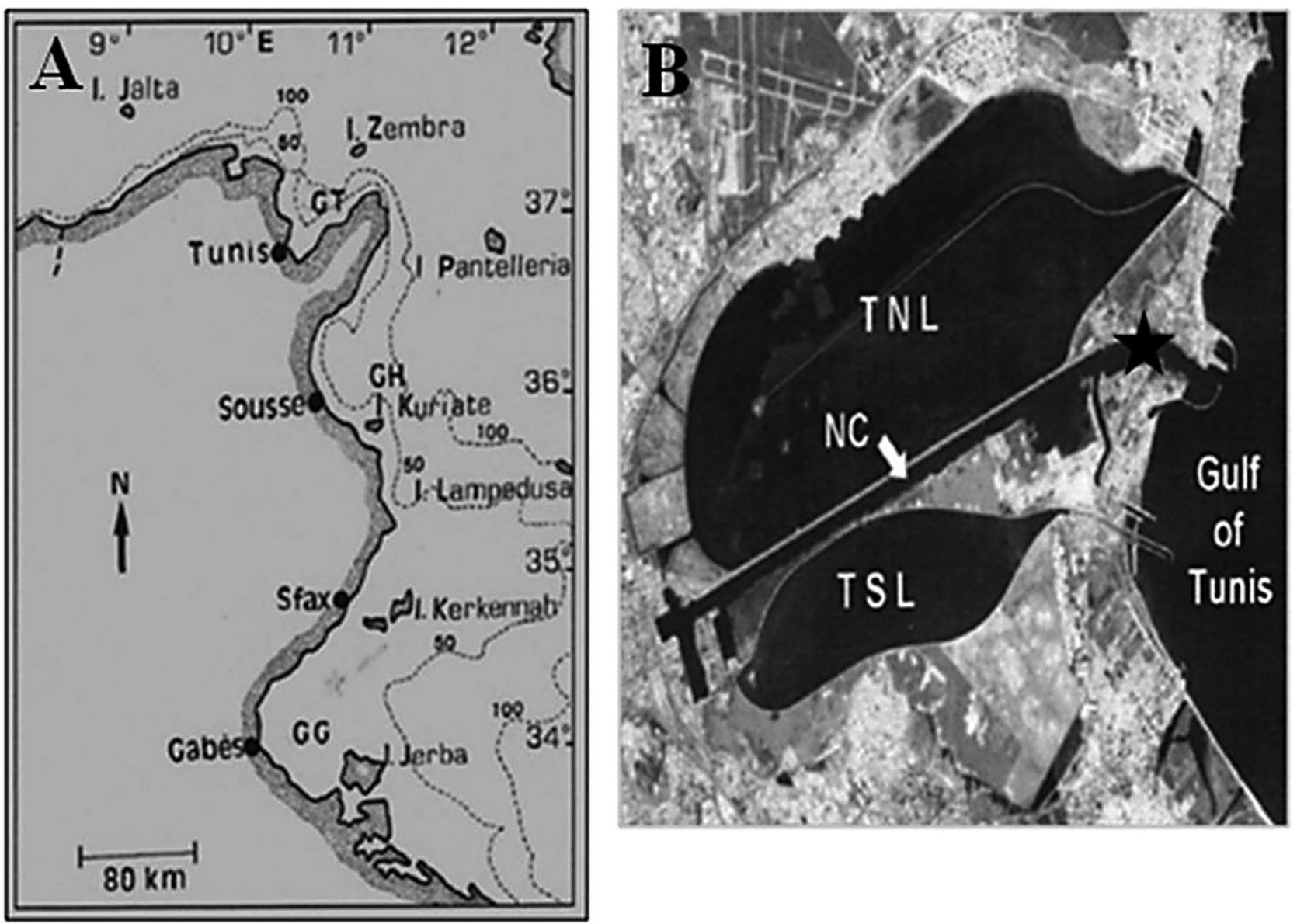

Fig. 1. - A, map of Tunisia with the Gulf of Tunis (GT), the Gulf of Hammamet (GH) and the Gulf of Gabes (GG). B, map of Tunis Lagoon divided by channel navigation (NC) in two areas Tunis Northern lagoon (TNL) and Tunis Southern Lagoon (TSL) and location of the sampling site inside the navigation channel.

es were taken with a digital Hamamatsu CCD camera. Semi thin sections of $0.5 \mu \mathrm{m}$ were cut with glass knives and stained with azure II-methylene blue and examined with a light microscope (Nikon, Melville).

For general light microscopic studies, posterior segments were fixed in alcoholic Bouin's fluid and prepared for conventional paraffin wax microscopy. After dehydration through ethanol series $(70 \%, 95 \%$ and $100 \%$ ) and storage in butylic alcohol, the fixed material was embedded in paraffin. Wax sections were cut at 5-7 $\mu \mathrm{m}$ and stained with hematoxylin-eosin technique.

\section{RESULTS}

\section{General morphology}

The ovaries of $M$. sanguinea are discrete organs and consist of coelomic germ-cell clusters surrounded by a thin envelope of follicle cells (= sheath cells according to Fischer, 1975) derived from the peritoneum (Fig. 2A). Clusters are attached to the genital blood vessels (Fig. 2B). Females usually have two clusters per segment except for the first segments. Oogenesis is extraovarian, asynchronized and is a continuous process. Therefore, germ cells in premeiotic and previtellogenic phases are observed in one cluster (Fig. 2B). In each cluster the more differentiated oocytes detach and float free in the coelomic cavity where they undergo vitellogenesis as solitary cells (Fig. 2C and D). Vitellogenesis takes place entirely outside the ovary.

\section{Stages of oogenesis}

Oogenesis consists of a proliferative phase followed by a prolonged growth phase resulting in the production of mature oocytes.

\section{Proliferative phase}

Two stages of premeiotic oocytes (I and II) are typically distinguished. The premeiotic oocytes I are small ( $8 \mu \mathrm{m}$ in diameter) and round shape cells characterized by a high nuclear-cytoplasmic ratio (Fig. 3A). Ooplasm is scarce and devoid of organelles except a few mitochondria and small cisternae of smooth endoplasmic reticulum (Fig. 3B). The size of the nucleus is about 6 to $7 \mu \mathrm{m}$ in diameter. A dense fibro-granular chromatin is scattered in the interphase stage. Premeiotic oocytes I appear to be bounded together by cytoplasmic bridges (Fig. 3C). The premeiotic oocytes II (Fig. 3D) which derived from the proliferation of the first one, have a lengthened shape and measure approximately $10 \times 12 \mu \mathrm{m}$. These cells are also characterized by a high nuclear-cytoplasmic ratio. They are found mixed in the 

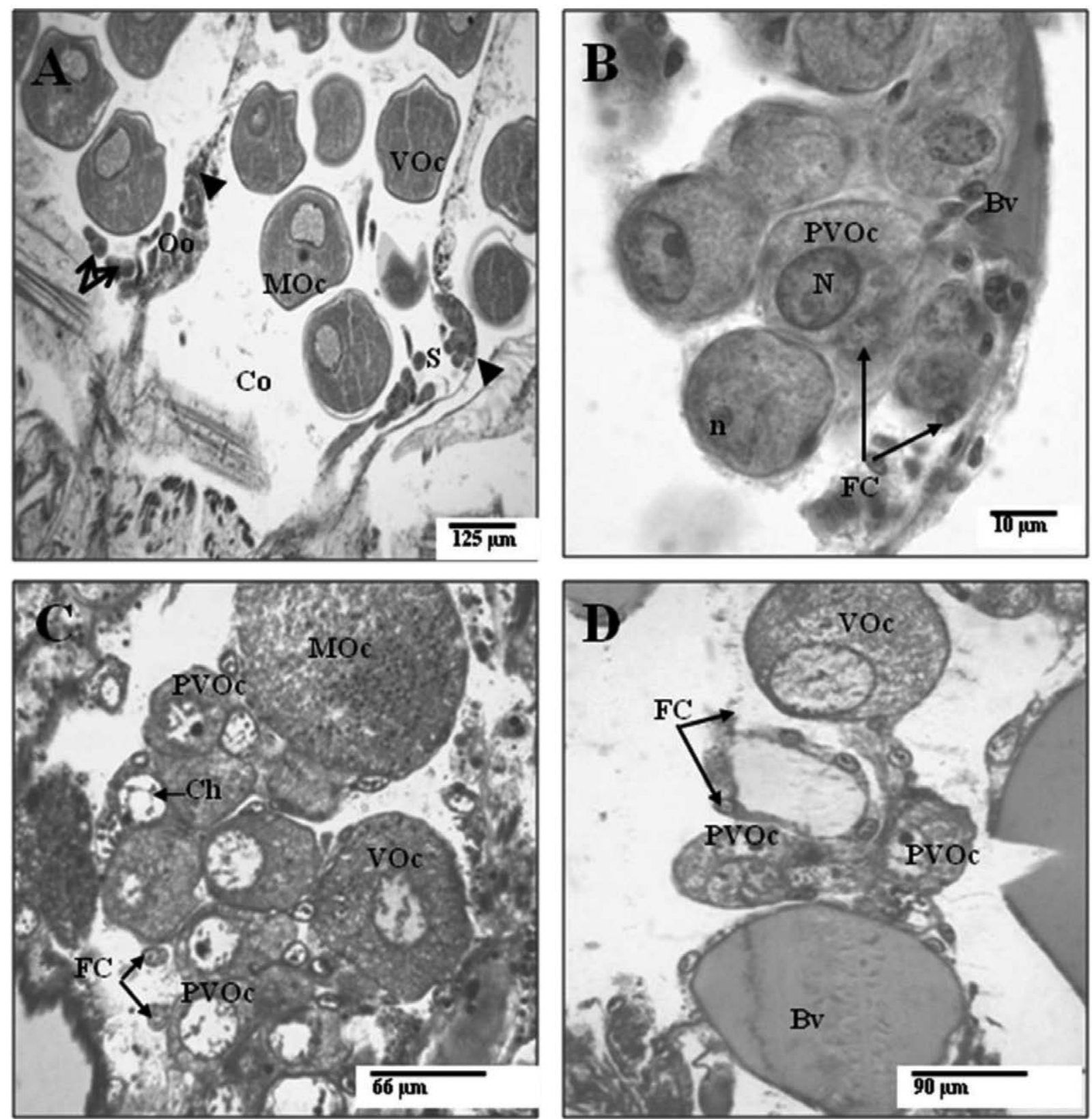

Fig. 2. - A, light micrograph of clusters of germ cells containing oogonia (Oo) and primary oocytes (arrows) within germinal sac (S); each packet is enveloped by a thin layer of somatic cell (arrowhead); note free vitellogenic and mature oocytes in the coelom. B, light micrograph of a cluster of germ cells attached to a blood vessel (Bv); note packets of follicle cells (FC) (arrows) surrounding previtellogenic oocytes (PVOc). C and D, light micrographs showing oocytes in various stages of meiotic division. Ch, chromatin; Co, coelom; MOc, mature oocyte; n, nucleolus; N, nucleus; VOc, vitellogenic oocyte.

cluster with the premeiotic oocytes I. The structure of the elongated nucleus is heterogeneous (Fig. 3D). The ultrastructural analysis reveals the peripheral condensation of the chromatin under the inner membrane of the nuclear envelope. Very small vesicles bud from the margins of the Golgi sacculi (Fig. 3E). The premeiotic oocytes II are solidly connected by maculae adherents. Following the proliferative phase, the first meiotic stage (leptotene) of the oocyte was observed (Fig. 4A).

\section{Previtellogenic oocytes}

Three categories (I, II and III) of previtellogenic oocytes are distinguished in M. sanguinea.

\section{Previtellogenic oocytes I}

The earliest previtellogenic oocytes measure 12 $\mu \mathrm{m}$ in diameter. These oocytes are in the first meiotic prophase and show the characteristic structures of synaptonemal complexes in the nucleus indicating the zygotene/pachytene stage of meiosis (Fig. 4B, inset). Synaptonemal complexes are composed of parallel peripheral and central elements. The cytoplasm, relatively homogeneous, is reduced and deprived of any vitelline structure (Fig. 4A). It is characterized by numerous distended cisternae of rough endoplasmic reticulum (RER) and fully developed Golgi complexes. Each Golgi complex consists of a stalk of flattened sac- 

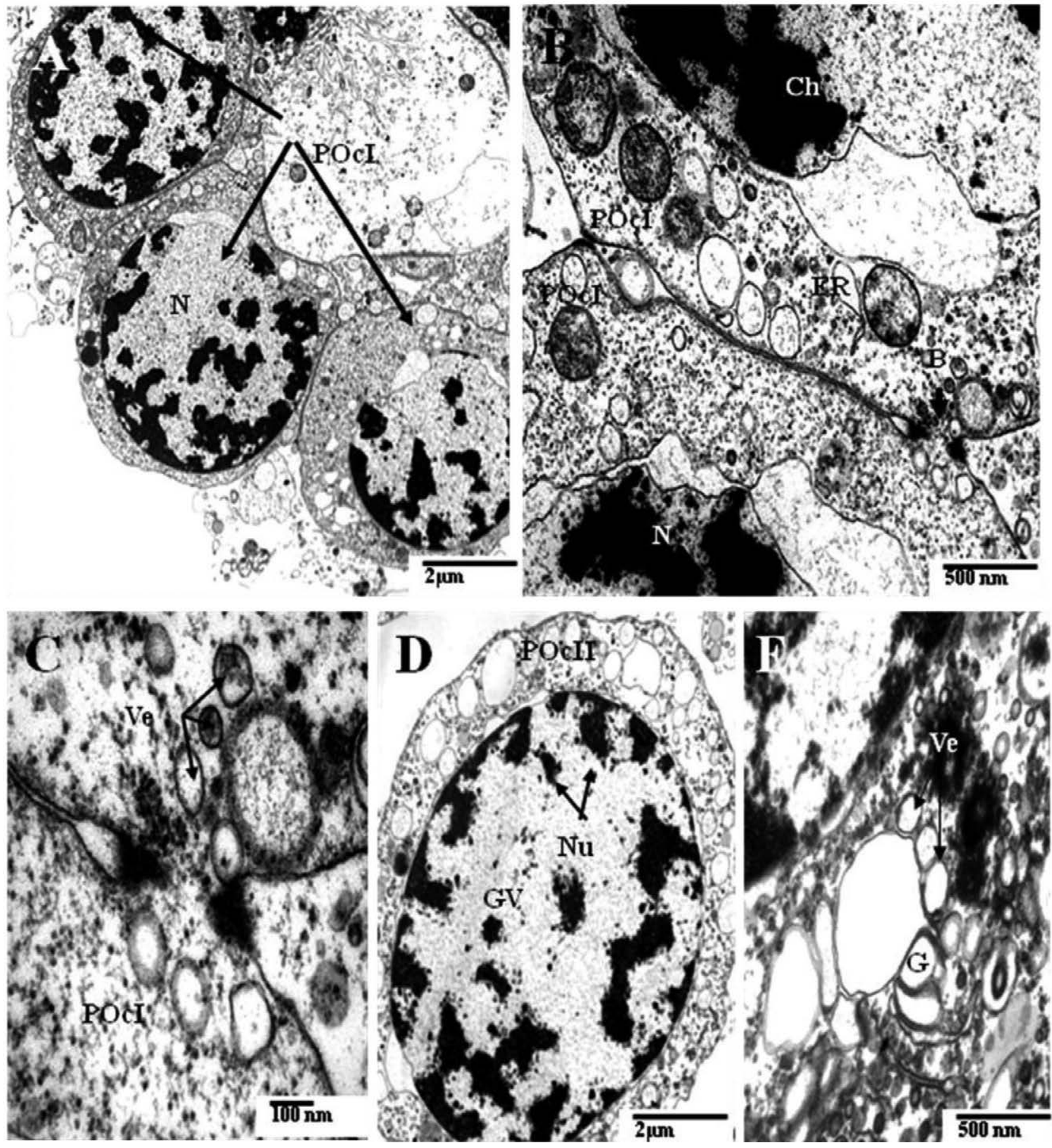

Fig. 3. - A, transmission electron micrograph (TEM) of small premeiotic oocytes I (POcI) (arrows); note large oocyte nuclei (N). B and C, TEM of coelomic cluster of premeiotic oocytes I connected by intercellular bridges (B); D, TEM of premeiotic oocyte II (POcII) showing large germinal vesicle (GV) with micro-nucleoli (Nu) (arrows); E, TEM of premeiotic oocyte II showing small Golgi vesicles (Ve) (arrows) in ooplasm adjacent to the nucleus (N). Ch, chromatin; ER, endoplasmic reticulum; G, Golgi complex.

culi (Fig. 4C). During the early previtellogenic stage, groups of oocytes are linked by intercellular bridges (Fig. 4D and E).

\section{Previtellogenic oocytes II}

These oocytes measuring 15 to $20 \mu \mathrm{m}$ in diameter are still attached to the common cytoplasmic mass. The nucleus enlarges compare to the previous stage to form what is now referred to as the germinal vesicle (diameter ranging from 8 to $9 \mu \mathrm{m}$ ). The spherical nucleus shows the characteristic structures of diplotene chromosomes which are localized near the nuclear envelope. The sacculi ( 7 to 8 ) of the Golgi complexes are clearly visible (Fig. 5A). Concurrently, there is an increase in the number of mitochondria with tubular cristae (Fig. 5B).

The external membrane of the nuclear envelope forms blebs intensively during this stage (Fig. 5C). At this time, oocytes are characterized by the onset of 

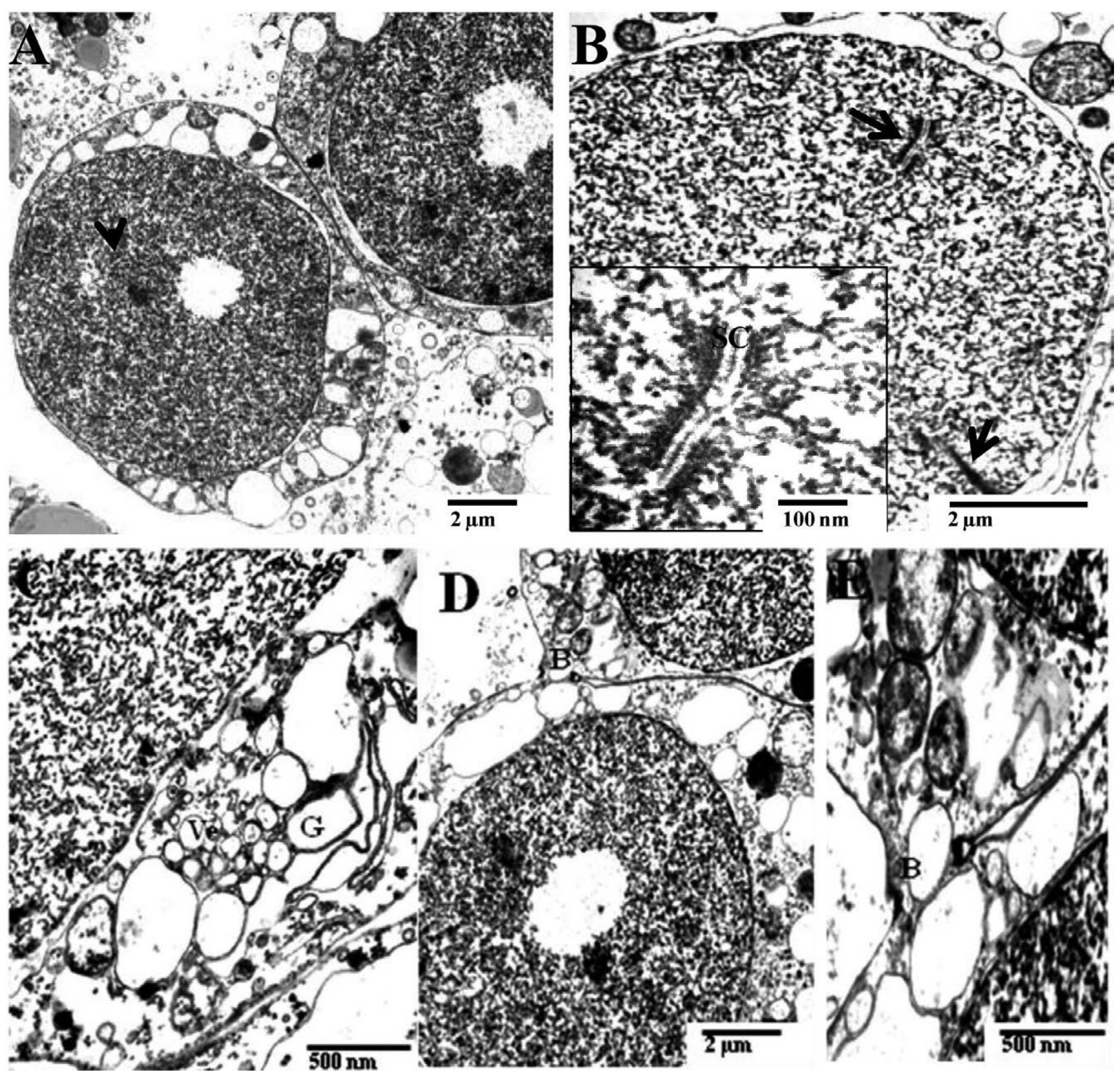

Fig. 4. - A, TEM of coelomic cluster of previtellogenic oocytes I ; arrowhead indicates homologous chromosomes. B, TEM of previtellogenic oocytes I showing paired chromosomes forming a synaptonemal complex (SC) (arrows); Inset: high magnification of a synaptonemal complex. C, Golgi complex in the ooplasm of a previtellogenic oocyte I; note the abundance of small and large vesicles (Ve) deriving from the Golgi complex (G) in the ooplasm. D, TEM of early previtellogenic oocytes connected by thin intercellular bridges (B). E, high magnification of intercellular bridges (B).

yolk deposition; lipid droplets appear near the nuclear envelope (Fig. 5C).

\section{Previtellogenic oocytes III}

Prior to the beginning of vitellogenesis, the oocytes increase in diameter. They begin to elongate and measure about 25-35 $\mu \mathrm{m}$ in length (Fig. 6A). Cytoplasmic continuity between cells observed in the premeiotic and early previtellogenic oocytes disappear and oocytes are now separated by clefts. Subsequently the previtellogenic oocytes III or the early vitellogenic oocytes break free from the clusters and float free in the coelomic cavity where they undergo yolk synthesis as solitary cells. Their cytoplasm contains a spherical germinal vesicle (18 $\mu \mathrm{m}$ in diameter) consisting of a porous envelope surrounding a finely granular material. There is an increase in size and number of perinuclear mitochondria. Some mitochondria exhibit tubulovesicular profiles. In late previtelloegnic oocytes, the first stages of yolk bodies appear and mark the start of the vitellogenic phase. Golgi complexes are distributed along the oolemma. At the same time, RER surrounds the forming yolk bodies (Fig. 6B).

Follicle cell-oocyte associations

Follicle cells are somatic, mesodermally derived cells that are associated with developing oocytes. By the end of previtellogenesis, clusters of follicle cells 

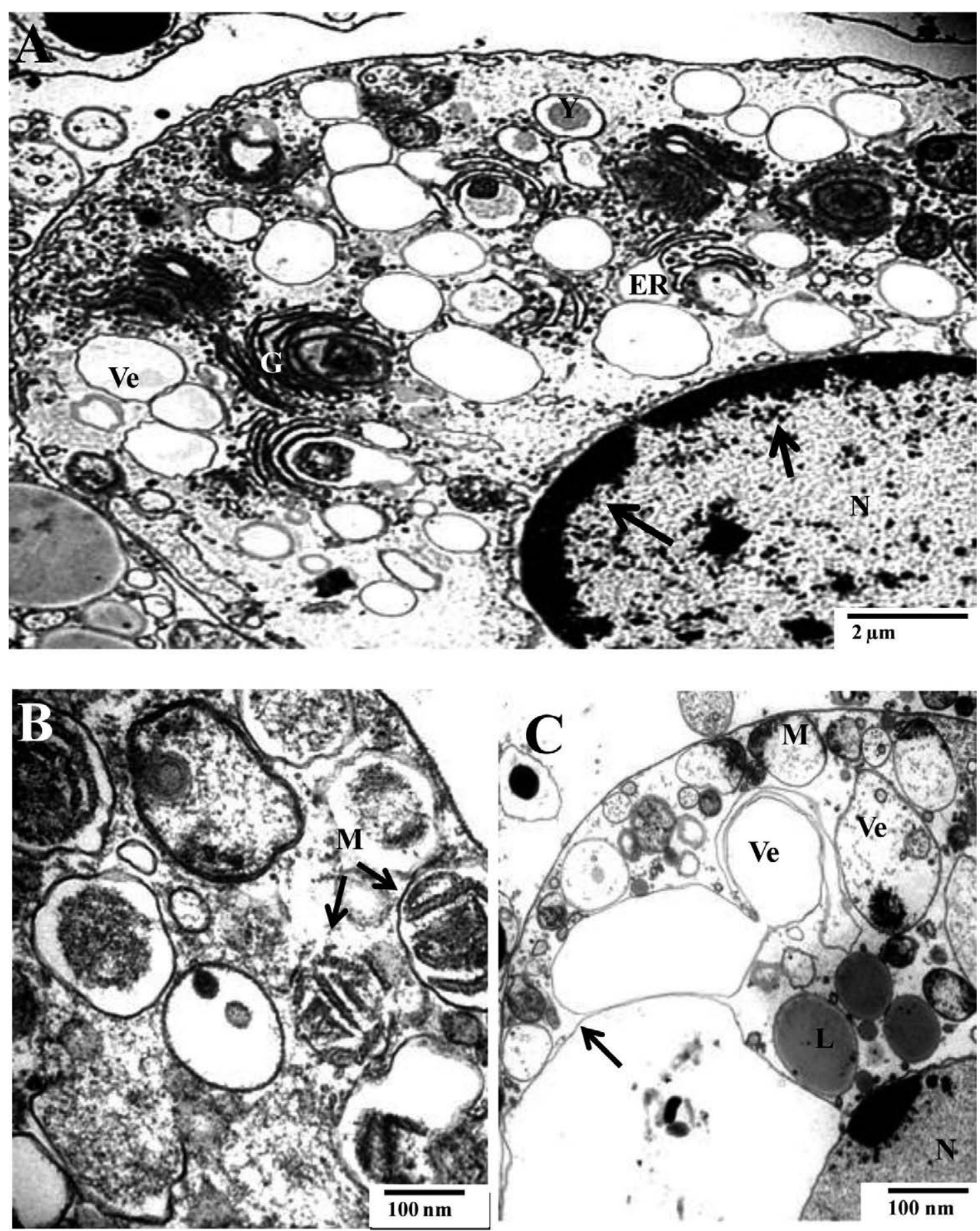

Fig. 5. - A, TEM of a previtellogenic oocyte II in diplotene stage of meiosis (arrows); note the nucleus (N) with distinct patches of heterochromatin under the nuclear envelope. B, scattered mitochondria (M) (arrows) with tubular cristae in the ooplams of a previtellogenic oocyte II. C, lipid droplets (L) near the nuclear envelope among distant vesicles (Ve) and mitochondria (M). ER, endoplasmic reticulum; G: Golgi complex; Y, yolk body.

surrounding the growing oocytes, maintain cytoplasmic continuity between these oocytes and assume probably a nutritive role (Fig. 7A). Follicle cells are connected with the oocytes by confluent cytoplasmic intercellular bridges (Fig. 7B). These modified peritoneal cells are irregular in thickness and contain a large oblong nucleus (Fig. 7A, inset) with scattered patches of peripheral condensed chromatin. The nucleolus was not observed but the outer membrane of the nuclear envelope is covered with ribosomes.
The most prominent feature observed in the follicle cells is the presence of abundant RER (Fig. 7C). Some free ribosomes are scattered in the cytoplasm as well as large oblong mitochondria with long tubular cristae. In addition we also observed some multivesicular bodies characteristic of lysosomes formation (Fig. 7D) and cytomembranes containing amorphous electron-dense material. The Golgi complexes have a small number of vesicles and are usually in close association with RER cisternae. The follicle cells plasmalemma is deeply 


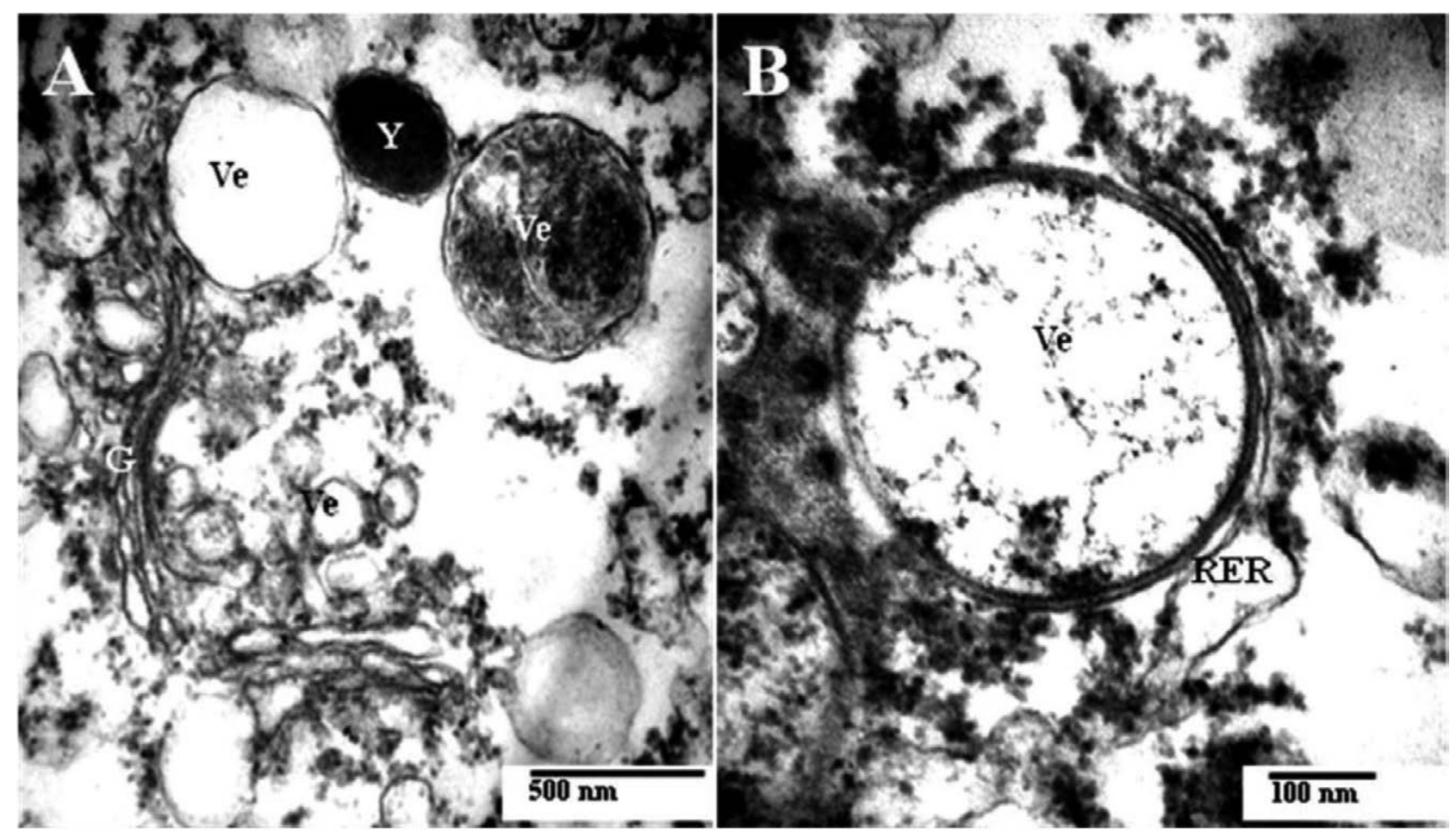

Fig. 6. - A, TEM of a previtellogenic oocyte III; vesicles deriving from the Golgi complex are visible. B, rough endoplasmic reticulum (RER) in close contact with Golgi vesicles (Ve).

folded and these folds develop into deep invaginations which seem to form channels throughout their cytoplasm (Fig. 7E). Follicle cells are in close apposition to developing oocytes but never possess microvilli or other elaborations of the plasmalemma. Adjacent follicle cells are attached to each other by small desmosomes (Fig. 7E). These data suggest that in the early stages of vitellogenesis, ribosomes, multivesicular bodies and dense bodies are transferred from the follicle cells to the oocytes through the intercellular bridges.

\section{Vitellogenic oocytes}

Vitellogenesis results in an increase in the volume of the oocyte largely due to the accumulation of nutritive material in the ooplasm. Oocytes are release from the packets into the coelom at the end of the previtellogenic phase or in the early vitellogenic phase, where they undergo yolk synthesis as solitary coelomic cells (Fig. 8A).

As oocyte growth proceeds, the egg envelope begin to develop and microvilli differentiate on the oocyte surface by folding of the oolema (Fig. 8B). The formation of the egg envelope begins in small vitellogenic oocytes (diameter comprises between 50 and $80 \mu \mathrm{m}$ ), containing a germinal vesicle measuring about $30 \mu \mathrm{m}$ in diameter. Groups of Golgi sacculi are scattered throughout the ooplasm, as well as numerous short cisternae of both smooth and rough endoplasmic reticulum. ER cisternae are often arranged along the proximal face of each Golgi complex (Fig. $8 \mathrm{C})$. The cytoplasm of early vitellogenic oocytes contains spherical vesicles of variable electron density (Fig. 8C and D). The small vesicles observed near the
Golgi complexes seem to originate from these organelles. They fuse to form large vesicles with variable electron density. Low-electron density vesicles fuse to form multivesicular like bodies in the cytoplasm of vitellogenic oocyte. The role of multivesicular-like bodies is undetermined but we suppose that they can be immature yolk bodies.

Yolk bodies are initially recognizable in early vitellogenic oocytes as small spherical membrane-bound bodies (60 $\mathrm{nm}$ in size) containing an electron-dense flocculum The flocculum within the vesicular bodies resembles that within the cisternae of the abundant endoplasmic reticulum, closely associated rough ER. Golgi complexes are observed in the cytoplasm which appear to be forming and releasing vesicles from their convex faces which are similar in size and electron density to those within the yolk bodies. As each yolk body continues to increase in diameter, it becomes bipartite with an inner electron-dense rod-shaped core which is often crystalline in appearance, and an outer lesselectron cortex (Fig. 8D and E). In larger and presumably more mature yolk bodies, the contents continue a process of condensation resulting in the formation of more homogeneous electron-dense core (Fig. 8E). Not uncommonly, mature yolk bodies surrounded by whorls of rough ER have been observed (Fig. 8F).

Endocytotic vesicles containing light moderate electron dense flocculum are often observed near the oolema (Fig. 8F). These vesicles migrate through the ooplasm to fuse with developing yolk bodies.

Following the completion of vitellogenesis the volume of the oocytes increases gradually due to the development of organelles such as mitochondria, RER and Golgi complexes which are involved in the production 

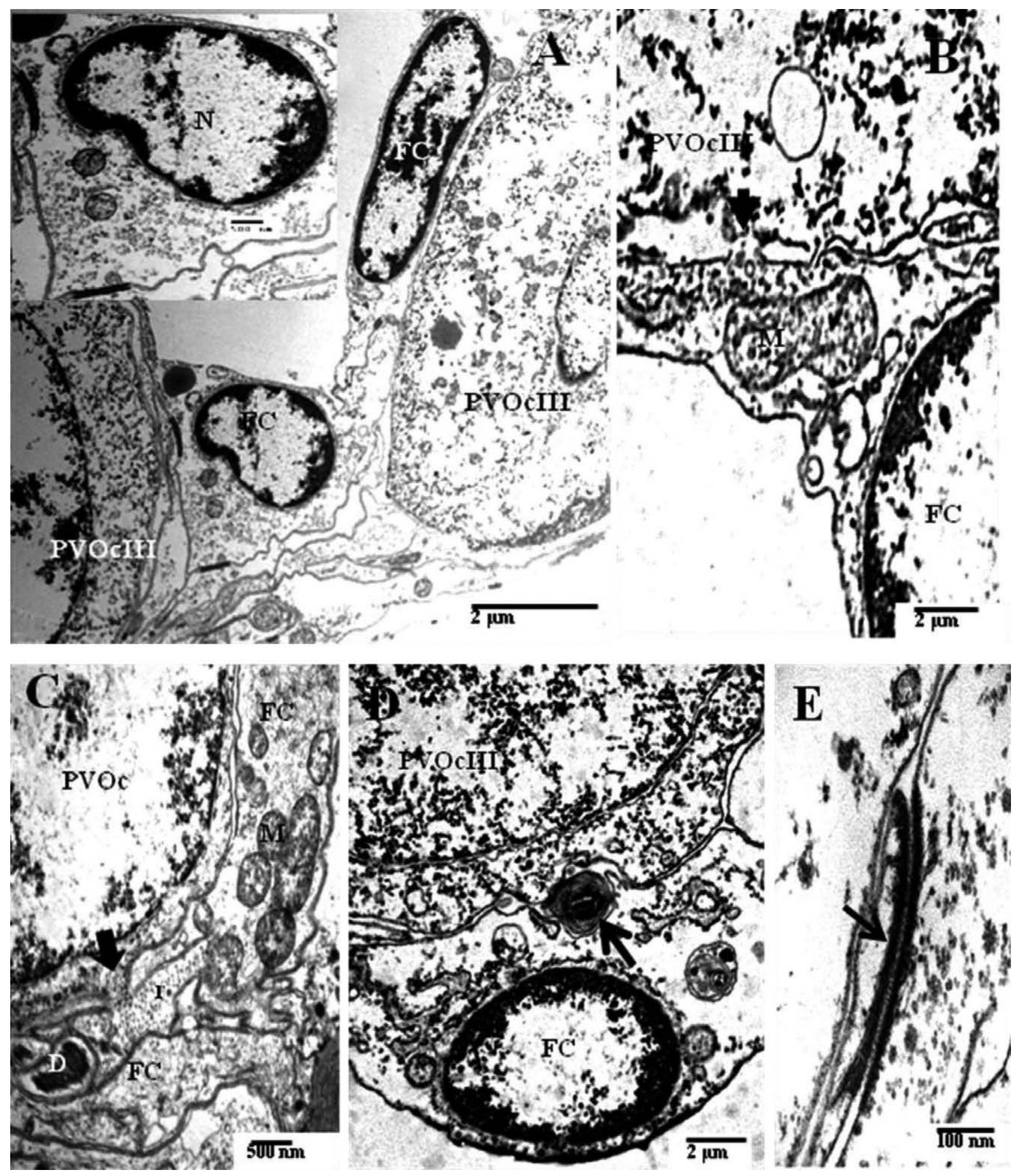

Fig. 7. - A, TEM of a previtellogenic oocyte III (PVOcIII) surrounded by follicle cells (FC) just before its detachment from the cluster; note the deeply folded plasma membrane of the follicle cells forming channels throughout the cytoplasm; Inset: large oblong nucleus (N) of a follicle cell. B, intercellular bridge between follicle cell and oocyte. C, mitochondria (M), rough endoplasmic reticulum (RER) and Golgi vesicles (Ve) in the cytoplasm of a follicle cell; arrow indicates ribosome in the intercellular bridges between follicle cell and oocyte. D, multivesicular bodies (arrow) in the cytoplasm of a follicle cell and in the space between a follicle cell and an oocyte. E, small desmosomal junction (arrow) between two adjacent follicle cells.

of cytoplasmic inclusions or yolk globules. Long strands of RER are observed throughout the ooplasm and gradually appear in parallel arrays (Fig. 9A and B). Sometimes endoplasmic cisternae surround the forming yolk bodies and lipid droplets (Fig. 9B, C and D). This close association between the ER and lipid droplets probably indicates the synthesis of lipoproteins. The ooplasm contains many lipid droplets and some yolk spheres lacking any crystalline formation .Typical lipid droplets exhibit sometimes a heterogeneous structure (Fig. 9C and D). Proteinaceaous yolk spheres appear firstly as lucent concentric rings then as homogeneous electron-opaque yolk 

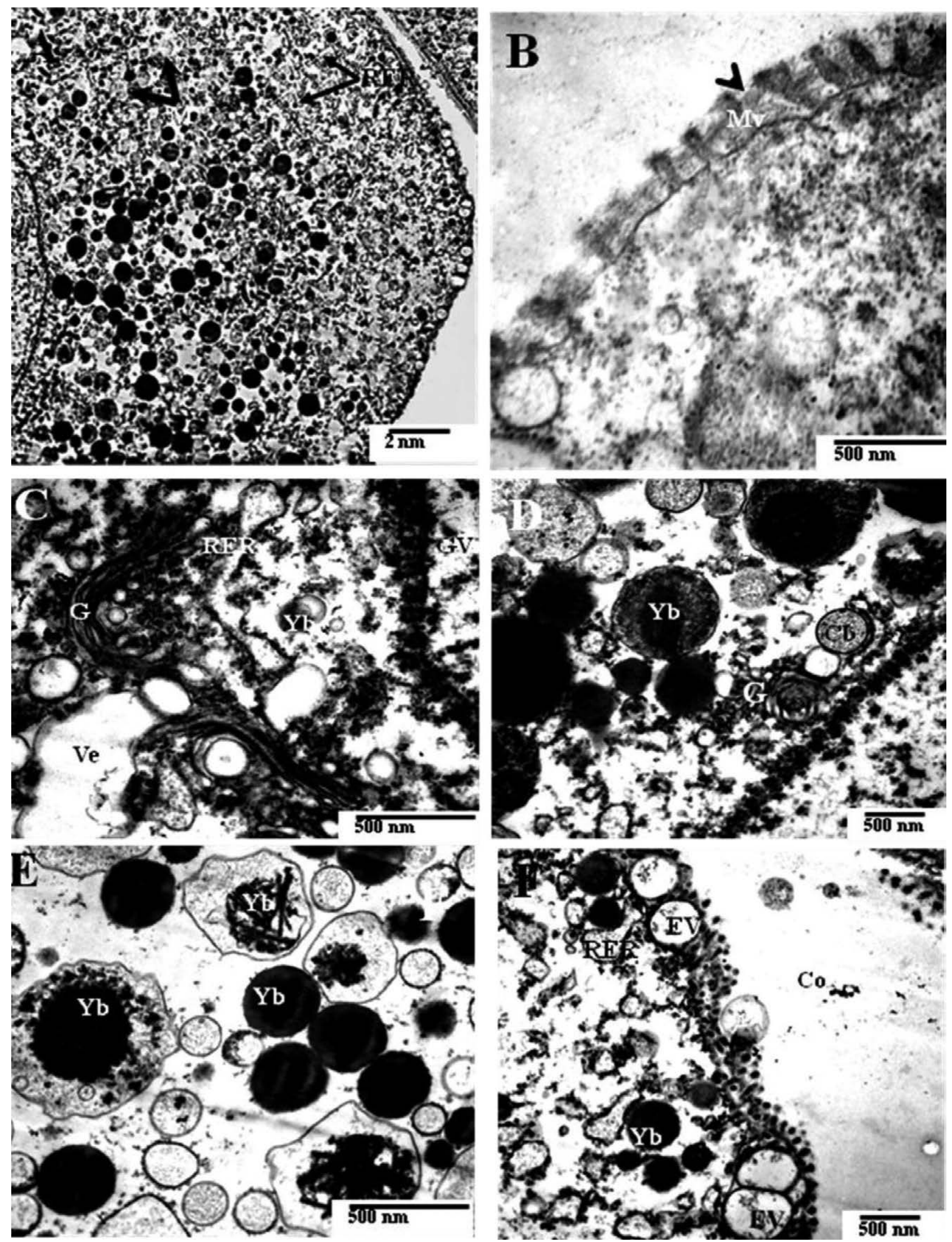

Fig. 8 - A, TEM of an early vitellogenic oocyte; note scattered mitochondria, Golgi complexes (arrows) and rough endoplasmic reticulum (RER, arrowed). B, early vitellogenic oocyte covered by vitelline envelope penetrated by newly formed microvilli (Mv). C, vesicles emerging from the forming face of the Golgi complex and the association of rough endoplasmic reticulum (RER). D and E, yolk body (Yb) in early, intermediate and late stages of formation. F, infolding of the oolema of an early vitellogenic oocyte and budding of coated endocytic vesicles (EV) that migrate through the ooplasm to fuse with developing yolk bodies. $\mathrm{Cb}$, core body; $\mathrm{Co}$, coelom; GV, germinal vesicle. 

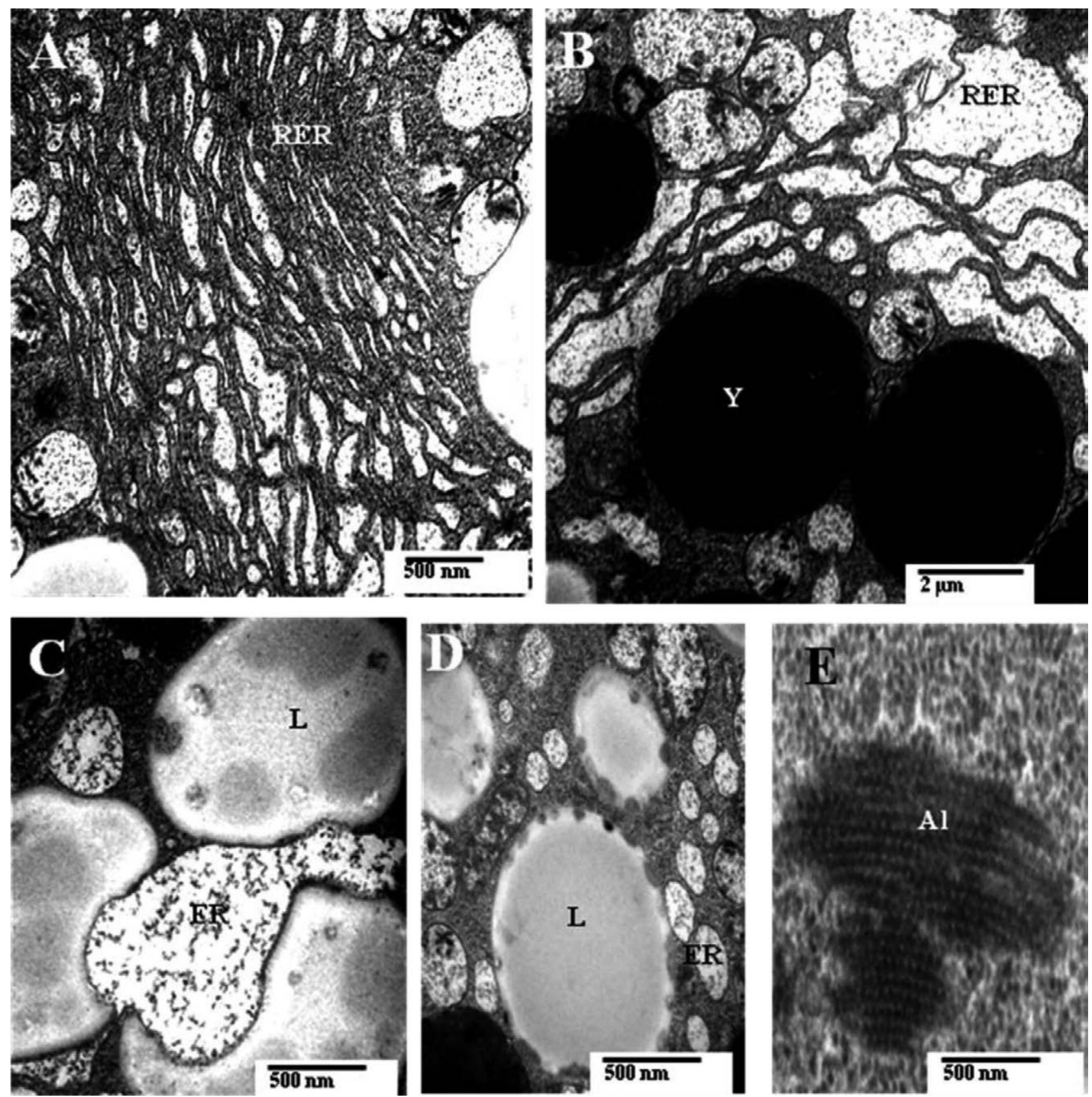

Fig. 9. - A and B, extensive parallel arrays of rough endoplasmic reticulum (RER) in the ooplasm of late vitellogenic oocyte. C and D, ERmembrane cisternae (ER) closely apposed to heterogeneous lipid droplets (L). E, annulate lamellae (Al). Y, yolk body.

droplets with a maximum diameter of about 2 m (Fig. 9B). Often they are somewhat irregular in outline. Clusters of mitochondria are scattered under the cortical zone and around the nucleus. Annulate lamellae, parallel arrays of fenestrated cytomembranes that closely resemble fragments of nuclear envelope, occur in the perinuclear ooplasm of sub-mature oocytes (approximately $200 \mu \mathrm{m}$ in size) (Fig. 9E).

Mature oocytes (250-300 $\mu \mathrm{m}$ in size) are characterized by a large eccentric nucleus with a distinct nucleolus (Fig. 10A). The nuclear envelope has an irregular outline with many shallow infolding and finger-like extensions into the perinuclear ooplasm (Fig. 10B and C). Nuclear membrane vesicles (Fig. 10D) containing aggregates of granulo-fibrillar material are closely associated with clusters of mitochondria (Fig. 10E). When the nucleus reaches approximately 40-50 $\mu \mathrm{m}$ in diameter, the nucleolus undergoes fragmentation or satellite formation (Fig. 10E). It is presumed that the aggregates of granulo-fibrillar are of nucleolar origin indicating a transfer of ribonucleoprotein particles from the nucleus to the ooplasm.

Mature oocytes are covered by an egg envelope. Regularly spaced microvilli protrude from the oocyte surface and, after penetrating the egg envelope, project into the medium with simple rounded tips (Fig. 10F). The egg envelope of mature oocytes reaches about 2.5 $\mu \mathrm{m}$ in thickness and is a complex 3-layered structure (Fig. 10F). The inner layer is thin (20 to $25 \mathrm{~nm}$ ) and is composed of slightly electron dense material. The 

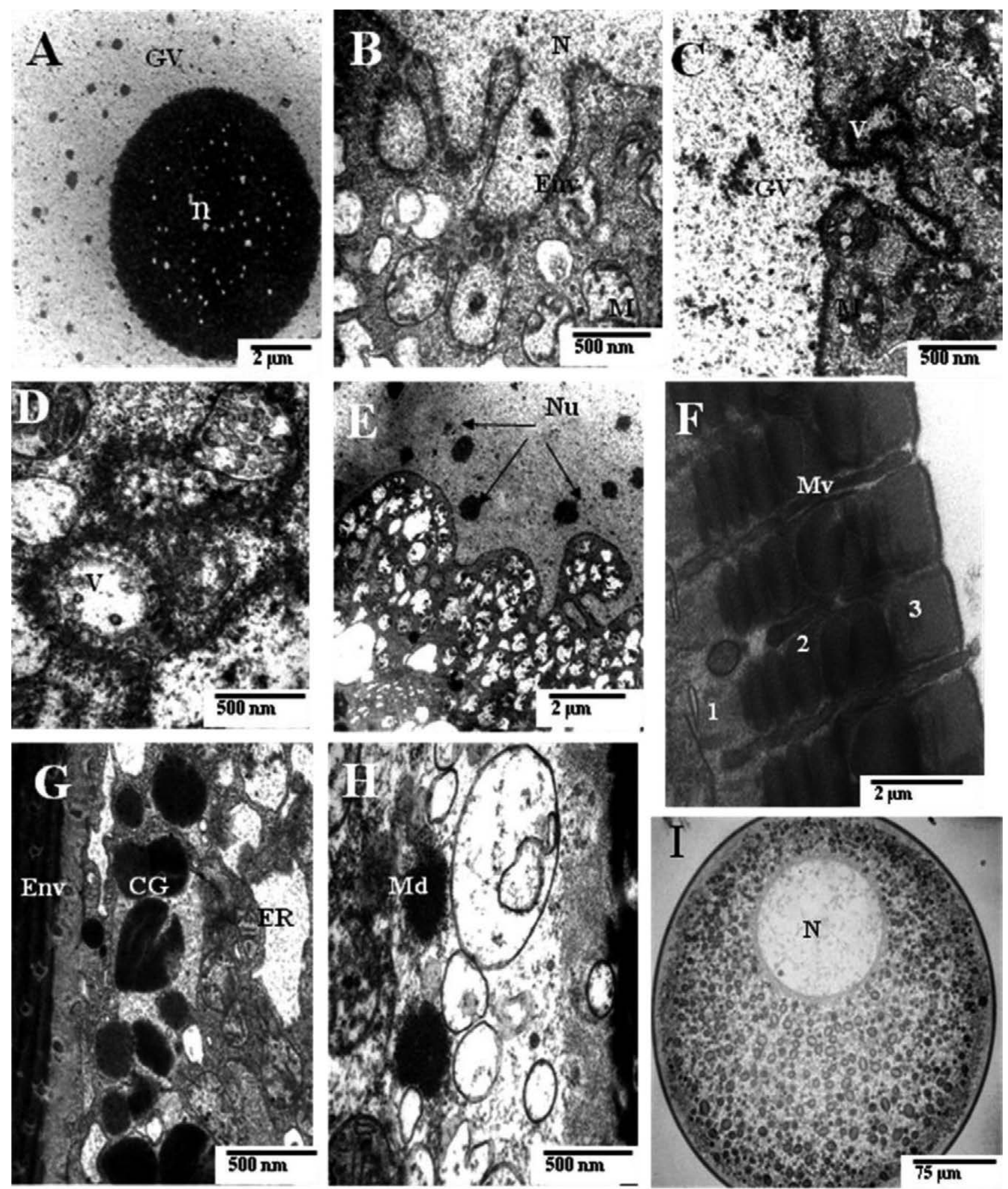

Fig. 10. - A, large nucleolus (n) in eccentric germinal vesicle (GV) of a mature oocyte. B and C, structure of the nuclear envelope (Env) of a mature oocyte; note the irregular outline of the nuclear envelope with many shallow infolding and finger-like extensions into the perinuclear ooplasm. D, higher magnification of the nuclear envelope showing the morphology of the flattened vesicles (V). E, germinal vesicle containing perinuclear micro-nucleoli ( $\mathrm{Nu}$ ) (arrows) and mitochondria clustered around the nucleus. F, higher magnification of the vitelline envelope; vitelline envelope consists of thin inner layer (1), middle thicker layer (2) and outer layer (3). G, cortical granules (CG) located in the peripheral ooplam layer of a mature oocyte. $\mathrm{H}$, cortical maternal determinant (Md) located in the animal pole of a mature oocyte. I, TEM of a mature oocyte showing the heterogeneous distribution of yolk bodies and lipid droplets into the cytoplasm. ER, endoplasmic reticulum; $\mathrm{M}$, mitochondria; Mv, microvillus, $\mathrm{N}$, nucleus.

intermediate layer is thick ( 35 to $55 \mathrm{~nm}$ ) and is recognized by complex strands of electron dense polysaccharide fibers. The outer layer is thinner (10 to $15 \mathrm{~nm}$ ) than the middle and inner layers and is composed of a less electron-dense material. The egg envelope contains about 55-62 microvillar tips/ $\mu \mathrm{m}^{2}$. 
Cytoplasmic material is asymmetrically distributed in the mature oocytes. Large lipid droplets $(1.5 \mu \mathrm{m}$ in size) and large yolk spheres (6 $\mu \mathrm{m}$ in size) occupy the vegetal pole of the oocyte while small yolk spheres (2-3 $\mu \mathrm{m}$ in size) and numerous membranous organelles (mitochondria, cisternae of endoplasmic reticulum) occupy the animal hemisphere (Fig. 10I). Moreover, spherical to elongated cortical granules up to $1.8 \mu \mathrm{m}$ in size are located in the cortex of the mature oocytes. These cortical granules have a paracrystalline inner structure (Fig. 10G). They contain the material that gives rise to the egg jelly after fertilization. Finally, fibrogranular aggregates ("nuage") similar to that within the nucleus are observed in the cortical ooplasm located in the animal pole of mature oocytes (Fig. 10H). These aggregates probably come from the nucleus and represent maternal cytoplasmic determinants of embryonic cell fate.

\section{DISCUSSION}

Few and mainly anecdotal data are available on oogenesis in the polychaetes of the family Eunicidae. $M$. sanguinea is a large-sized gonochoric species with annual iteroparous strategy and synchronous spawning at population level (Prevedelli et al. 2007).

\section{Type of oogenesis}

In $M$. sanguinea extraovarian oogenesis occurs in which late previtellogenic or early oocytes are release into the coelom from a simple ovary where differentiation occurs in association with follicle cells. The ovary consists of coelomic germ-cell clusters communicating via intercellular bridges surrounded by a thin envelope of follicle cells. As observed for the majority of polychaetes with extraovarian oogenesis, oocytes rupture through the epithelium prior to vitellogenesis and disperse independently in the coelom. Polychaetes belonging to other families (Dorvillaeidae, Onuphidae) in the order Eunicida studied until now are also characterized by an extraovarian oogenesis (Eckelbarger, 1983). Nevertheless, contrary to what occurs in other eunicids studied up to now, previtellogenic oocytes are not associated with nurse cells in $M$. sanguinea. Oocyte growth begins after the initiation of meiotic prophase and includes an increase in the number of mitochondria, RE and active Golgi apparatus. Due to the presence of previtellogenic, vitellogenic and sometimes mature oocytes in the coelome of females we deduce that $M$. sanguinea has an asynchronous oogenesis.

\section{Functions of follicle cells}

Follicle cells are somatic, mesodermally derived cells that are associated with developing oocytes. They are usually thin, squamous cells but they can undergo hypertrophy during vitellogenesis in some species (Eckelbarger, 2005). They show great variation in their degree of temporal association with oocytes. For a large number of polychaete species, these accessory cells serve a mechanical, supporting function rather than a nutritive one (Eckelbarger 2005). In the majority of polychaete species studied up to now follicle cells lack cytoplasmic continuity with oocytes but may form junctional complexes with the underlying oocytes (Eckelbarger 2005). Nevertheless, Rouse and Tzetlin (1997) showed that follicle cells in the ovary of Cossura cf. longocirrata contact the underlying oocytes via cytoplasmic bridges. We also noticed the presence of cytoplasmic bridges between young oocytes and follicle cells in $M$. sanguinea. So, the variation in $M$. sanguinea is unusual.

Contrary to what occurs in many other polychaete species, cytoplasmic organelles are well developed in the follicle cells and there is morphological evidence for the transfer of material from the follicle cells to the developing oocytes for use in yolk synthesis in $M$. sanguinea.

\section{Yolk synthesis}

Nearly all of the polychaete species studied until now utilize some form of "mixed" yolk synthesis involving both autosynthetic and heterosynthetic processes (Eckelbarger, 2005). Autosynthesis involves the manufacture of yolk bodies via the proteosynthetic organelles of the oocyte whereas heterosynthetic involves the production of female-specific yolk proteins that are incorporated into the oocyte through a receptor-mediated process of endocytosis. Different morphological evidence supports the heterosynthetic and autosynthetic origin of yolk in $M$. sanguinea. Autosynthetic yolk formation in $M$. sanguinea involves proteosynthetic organelles (RER and Golgi complexes). The RER cisternae often swell and become distended with product and transition vesicles from the RER fuse with the forming face of the Golgi complex. Progressively larger yolk bodies result from the fusion of secretory vesicles released from the maturing face of the Golgi complex. In $M$. sanguinea, the external membrane of the nuclear envelope of previtellogenic oocyte II forms blebs. The same process has been reported in another species of Eunicida Diopatra cuprea (Anderson and Huebner 1968). In his description of the mechanism of synthesis of yolk in crustacean oocytes Kessel (1968) emphasized the part played by the external membrane of the nuclear envelope in the process of the formation of new vesicular cisternae of the ER needed for yolk synthesis. The constant demand for new ER vesicles somehow stimulates the nuclear envelope to produce them.

Heterosynthetic yolk formation in M. sanguinea involves initially nutrient transfer between follicle cells and earliest oocyte, endocytosis of yolk precursors from the coelomic fluid and entry of low molecular weight precursors in the oocyte through the abundant microvilli which adorn the surface of the egg. Both synthetic activities are also involved in the oogenesis of other Eunicida species: Diopatra cuprea and Diopatra neopolitina (Eunicida: Onuphidae, Anderson and Huebner 1968, El Gabsi 2001). 


\section{Mature oocytes}

Oocytes that had completed vitellogenesis measure 280-300 $\mu \mathrm{m}$. The same diameter of mature oocytes was measured in females collected in the Venice Lagoon (Prevedelli et al. 2007).

Polychaete eggs are known to contain various types of nutritive materials including lipid droplets and membrane-bound protein yolk-bodies. Mature oocytes display a wide range of egg envelope morphologies (reviewed in Eckelbarger 2005). The thickness of the egg envelope of mature oocytes in $M$. sanguinea $(2.5$ $\mu \mathrm{m})$ is thicker than commonly found in polychaetes $(<1 \mu \mathrm{m})$ but it can reach $4 \mu \mathrm{m}$ in the amphinomid Benthoscolex sp. (in Eckelbarger 2005). In mature eggs, the egg envelope is invariably penetrated by the tips of the oocyte microvilli, putting the egg in direct contact with its environment. In many instances, the microvilli have simple rounded tips while others bifurcate or bear extensive filamentous adornments. The microvilli usually develop a filamentous glycocalyx along their surface and the perivitelline space between microvilli gradually fills in with one or more layers of extracellular material.

In $M$. sanguinea, the formation of microvilli begins in early vitellogenic oocytes. The density of the microvillar tips in the mature oocyte of $M$. sanguinea (55-62 microvillar tips/um) is comparable to that described for the spionid Marenzellaria viridis (50-60 microvillar tips/um, Bochert 1996). The high density of microvilli tips increases the available surface area of the oocyte, as described for the nereid Platynereis dumerilii where microvilli form about $14.6 \%$ of the whole egg membrane surface (Kluge et al. 1995) and for the onuphid Diopatra cuprea (Anderson and Huebner, 1968). This feature may facilitate the uptake of low molecular weight precursors through the oolema (see Huebner and Enderson 1976). As for Capitella jonesi (Eckelbarger and Grassle 1982), we suppose that the development of oocyte microvilli, endocytotic activity and yolk synthesis also occurs concomitantly with differentiation of the follicle cells, suggesting a temporal and functional correlation. Surface microvilli probably function in absorbing low-molecular weight precursors and vital metabolites during oocyte differentiation. The microvilli were usually interpreted to be a route for transporting substances from the outside into oocytes in most of polychaete species examined, regardless of whether the species shows endocytotic activity or not during oogenesis (Dhainaut 1967, 1970, 1976, King et al. 1969, Postwald 1972, Eckelbarger 1976, 1980, Eckelbarger and Grassle 1982).

Two cortical structures were detected in the mature oocytes of $M$. sanguinea: cortical maternal determinant and cortical granules. Cortical granules are of Golgi origin and are involved in the fertilization reaction (Eckelbarger 2005). Cortical granules are prominent within oocytes in several polychaetes species and are usually small organelles $0.5-2 \mu \mathrm{m}$ in size (for review see Eckelbarger 1988). Only one type of cortical granules is present in mature oocytes of $M$. sanguinea as in the majority of the polychaetes (Bochert 1996).
However two types of cortical granules, different in internal structure (but only slightly in size) can be distinguished in Nereis diversicolor (Pasteels 1966, Dhainaut 1969) and Tylorrhynchus heterochaetus (Takashima and Tominaga 1978), although the authors erroneously designated one type as "cortical alveoli" (see Guraya 1982, cf. Pasteels 1965, Fallon and Austin 1967, Dhainaut 1984). Cortical maternal determinant is implicated in formation, the differentiation of tissues, the morphogenesis and differentiation of the embryo.

The cytoplasmic material of the mature oocytes is asymmetrically distributed; large lipid droplets and large yolk spheres occupy the vegetal pole of the oocyte while smaller yolk spheres are situated in the animal hemisphere. The same type of eggs was observed in many other species of polychaetes such as Diopatra cuprea (Anderson and Huebner 1968), Platynereis dumerilii (Dorresteijn 1990) and Nereis virens (Dondua et al. 1997). It can be hypothesized that the differential distribution of cytoplasmic components leads to qualitative differences in blastomere cytoplasm. Elsewhere it has commonly been thought that these differences are responsible for the process of cell diversification and embryonic axis formation in early stages of embryonic development (Goldstein and Freeman 1997).

As for many species of polychaetes, in addition to yolk bodies and lipid droplets, the mature oocytes of $M$. sanguinea also contain ooplasmic annulate lamellae but their function is still unknown (reviewed in Eckelbarger 1988, 1992, 2005).

\section{ACKNOWLEDGEMENTS}

The authors would like to thank Professor Albert Fischer and Ulrich Hoeger from Institut of Zoology, Johannes Gutenberg-Universität, Main for very valuable comments on this manuscript.

\section{REFERENCES}

Anderson E., Huebner E. 1968. Development of the oocyte and its accessory cells of the polychaete Diopatra cuprea (Bosc.). J. Morph. 126: 163-197.

http://dx.doi.org/10.1002/jmor. 1051260203

Bochert R. 1996. An electron microscopic study of oogenesis in Marenzelleria viridis (Verrill 1873) (Polychaetea; Spionidae) with special reference to large cortical alveoli. Invert. Reprod. Develop. 29: 57-69.

http://dx.doi.org/10.1080/07924259.1996.9672495

Dhainaut A. 1967. Etude de la vitellogenèse chez Nereis diversicolor O.F. Müller (Annélide Polychète) par autoradiographie à haute résolution. C.R. Hebd. Seances Acad. Sci. Ser. D. 265: 434-436.

Dhainaut A. 1969. Origine et structure des formations mucopolysacharidiques de la zone corticale de l'ovocyte de Nereis diversicolor O.F. Müller (Annélide Polychète). J. Microsc. 8: 69-86.

Dhainaut A. 1970. Etude cytochimique et ultrastructurale de l'évolution ovocytaire de Nereis pelagica L. (Annélide Polychète) I. Ovogenèse naturelle. Z. Zellforsch. Microsc. 104: 345-390.

Dhainaut A. 1976. Contrôle hormonal de la biosynthèse des glycoconjugués chez l'ovocyte de Perinereis cultrifera (Annélide Polychète). Etude autoradiographique. In Actualités sur les hormones des invertébrés. Colloq. Int. C.N.R.S. 251: 83-92.

Dhainaut A. 1984. Oogenesis in Polychaetes. Ultrastructural differentiation and metabolism of nereid oocytes. In: Fischer A., and H.D. Pfannenstiel H.D. (eds), Polychaete Reproduction. Fortschr. Zool. 29: 183-205. 
Dondua A.K., Kostyuchenko R.P., Fedorova Z.E. 1997. Effects of some cytoskeleton inhibitors on ooplasmic segregation in the Nereis virens egg., Int. J. Dev. Biol. 41: 853-858.

Dorresteijn A.W.C. 1990. Quantitative analysis of cellular differentiation during early embryogenesis of Platynereis virens. Roux's Arch. Dev. Biol. 199: 14-30. http://dx.doi.org/10.1007/BF01681530

Eckelbarger K.J. 1976. Origin and development of the amoebocytes of Nicolea zostericola (Polychaeta: Terebellidae) with a discussion of their possible role in oogenesis. Mar. Biol. 36: 169-182. http://dx.doi.org/10.1007/BF00388440

Eckelbarger K.J. 1980. An ultrastructural study of oogenesis in Strebtospio benedicti (Spionidae), with remarks on diversity of vitellogenic mechanisms in Polychaeta. Zoomorph. 94: 241263. http://dx. doi.org/10.1007/BF00998204

Eckelbarger K.J. 1983. Evolutionary radiation in polychaete ovaries and vitellogenic mechanisms: their possible role in life history patterns. Can. J. Zool. 61: 487-504. http://dx doi.org/10.1139/z83-065

Eckelbarger K.J. 1984. Comparative aspects of oogenesis in polychaetes. In Fischer A., Pfannenstiel H.D. (eds), Polychaete reproduction, Progress in Comparative Reproduction Biology, Fortschr. Zool. 29: 123-148.

Eckelbarger K.J. 1988. Oogenesis and female gametes. In Westheide W., Hermans C.O. (eds), The Ultrastructure of Polychaeta, Microfauna Mar. 281-307.

Eckelbarger K.J. 1992. Oogenesis. In Harrison, F.W., Gardiner S.L. (eds), Microscopic Anatomy of Invertebrates, Vol. 7, Chapter 2 (Polychaeta). Wiley-Liss Inc., New York, 109-127.

Eckelbarger K.J. 2005. Oogenesis and oocytes. In: Bartolomeus T., Purschke G. (eds), Morphology, Molecules, Evolution and Phylogeny in Polychaeta and Related Taxa. Hydrobiologia 535/536: 179-198.

Eckelbarger K.J. 2006. Oogenesis. In: Rouse G, Pleijel F (eds) Reproductive biology and phylogeny of Annelida. Science Publishers, Plymouth, pp. 23-43

Eckelbarger K.J., Grassle J.P. 1982. Ultrastructure of the ovary and oogenesis in the polychaete Capitella jonesi (Hartman, 1959). J. Morph. 171: 305-320. http://dx.doi.org/10.1002/jmor.1051710306

El Gabsi T. 2001. Biologie de la reproduction d'une Annélide Polychète Diopatra neapolitana. Thèse de 3e Cycle. Fac. Sci. Math. Phys. et Nat. de Tunis, 259 pp.

Fallon J.F., Austin C.R. 1967. Fine structure of gametes of Nereis limbata (Annelida) before and after interaction. J. Exp. Zool. 166: 225-242. http://dx.doi.org/10.1002/jez.1401660205

Fauvel P. 1923. Polychètes Errantes, Faune de France, vol. 5, 488 pp.

Fischer, A. 1975. The structure of symplasmic early oocytes and their envelopping sheath cells in the Polychaete Platynereis dumerilli. Cell Tissue Res. 160: 327-343.

Giangrande A. 1997. Polychaete reproductive patterns, life cycles and life histories: an overview. Ocean. Mar. Biol. Ann. Rev. 35: 323-386.

Goldstein B., Freeman G. 1997. Axis specification in animal development. Bioessays. 19: 105-116. http://dx.doi.org/10.1002/bies.950190205

Gurraya S.S. 1982. Recent progress in, the structure, origin, com- position and function of cortical granules in animal egg. Int. Review Cytol. 78: 237-260.

Huebner E., Anderson E. 1976. Comparative spiralian oogenesis structural aspects: an overview. Amer. Zool. 16: 315-343.

Hutchings P.A., Karageorgopoulos, P. 2003. Designation of a neotype of Marphysa sanguinea (Montagu, 1813) and a description of a new species of Marphysa from eastern Australia. Hydrobiologia, 496: 87-94. http://dx.doi.org/10.1023/A:1026124310552

Kessel R.G. 1968. Mechanisms of protein yolk synthesis and deposition in crustacean oocytes. Z. Zellforsch. Microsc. 89: 17-38. http://dx.doi.org/10.1007/BF00332649

King P.E., Bailey J.H., Babbage P.C. 1969. Vitellogenesis and formation of the egg chain in Spirorbis borealis (Serpulidae). J. mar. biol. Ass. U.K. 49: 141-150. http://dx.doi.org/10.1017/S0025315400046476

Kluge B., Lehmann-Greif M., Fischer A. 1995. Long-lasting exocytosis and massive structural reorganization in the egg periphery during cortical reaction in Platynereis dumerilii (Annelida, Polychaeta). Zygote 3: 141-156. http://dx.doi.org/10.1017/S0967199400002513

Lewis C., Karageorgopoulos P. 2008. A new species of Marphysa (Eunicidae) from the Western Cape of South Africa. J. mar. biol. Ass. U.K. 88: 277-287.

Montagu G. 1815. Descriptions of several new or rare animals, principally marine, discovered on the South coast of Devonshire. Trans. Linnean Soc. London 11: 1-26. http://dx.doi.org/10.1111/j.1096-3642.1813.tb00035.x

Pasteels J.J. 1965. Etude au microscope électronique de la réaction corticale. I. La réaction corticale de fécondation chez Paracentrotus et sa chronologie. II. La réaction corticale de l'œuf vierge de Sabellaria alveolata. J. Embryol. Exp. Morph. 13: 327-339.

Pasteels J.J. 1966. La réaction corticale de fécondation de l'œuf de Nereis diversicolor, étudiée au microscope électronique. Acta Embryol. Morphol. Exp. 9: 155-163.

Postwald H.E. 1972. The relationship of early oocytes to putative neoblasts in the serpulid Spirorbis borealis. J. Morphol. 137: 215-229. http://dx.doi.org/10.1002/jmor.1051370207

Prevedelli D., Massamba N'Siala G., Ansaloni I, Simonini R. 2007. Life cycle of Marphysa sanguinea (Polychaeta: Eunicidae) in the Venice Lagoon (Italy). Mar. Ecol. 28: 384-393. http://dx.doi.org/10.1111/j.1439-0485.2007.00160.x

Rouse G.W., Pleijel F. 2001. Polychaetes. Oxford University Press, New York, 354 pp.

Rouse G.W., Tzetlin A.B. 1997. Ultrastructure of the body wall and gametogenesis in Cossura cf. longoccirrata (Cossuridae Polychaeta). Invert. Reprod. Dev. 32: 41-54. http://dx.doi.org/10.1080/07924259.1997.9672603

Schroeder P.C., Hermans C.O. 1975. Annelida: Polycheata. In: Giese A.C., Pears J.S. (eds), Reproduction of Marine Invertebrates. Vol. III. Annelids and Echiurans. Academic Press, New York, $213 \mathrm{pp}$.

Takashima Y., Tominaga A. 1978. Ultracytochemistry on the cortical granules and cortical alveoli of Japanese palolo eggs. Acta Histochem. Cytochem. 11: 171-179. http://dx.doi.org/10.1267/ahc.11.171

Wilson W.H. 1991. Sexual reproductive modes in polychaetes: classification and diversity. Bull. Mar. Sci. 48: 500-516. 